\title{
Characterization of Refuse Derived Fuel Production from Municipal Solid Waste: The Case Studies in Latvia and Lithuania
}

\author{
Dace ĀRIN̦A ${ }^{1 *}$, Rūta BENDERE², Gintaras DENAFAS ${ }^{3}$, Jānis KALNAČS ${ }^{4}$, \\ Mait KRIIPSALU ${ }^{5}$ \\ ${ }^{1,4}$ Institute of Physical Energetics, 11 Krìvu Street, LV-1006, Riga, Latvia \\ ${ }^{2}$ Department of Environmental Science, University of Latvia, 19 Raina Blvd., LV-1586, Riga, Latvia \\ ${ }^{3}$ Department of Environmental Technology, Kaunas Technological University, Radvilenu pl. 19, C-505, \\ LT-50254, Kaunas, Lithuania \\ ${ }^{5}$ Department of Water Management, Estonian University of Life Sciences, Kreutzwaldi 5, 51014, Tartu, \\ Estonia
}

\begin{abstract}
The authors determined the morphological composition of refuse derived fuel (RDF) produced in Latvia and Lithuania by manually sorting. The parameters of RDF (moisture, net calorific value, ash content, carbon, nitrogen, hydrogen, sulphur, chlorine, metals) was determined using the EN standards. Comparing obtained results with data from literature, authors have found that the content of plastic is higher but paper and cardboard is lower than typical values. Results also show that the mean parameters for RDF can be classified with the class codes: Net heating value (3); chlorine (3); mercury (1), and responds to limits stated for $3^{\text {rd }}$ class of solid recovered fuel. It is recommended to separate biological waste at source to lower moisture and ash content and increase heating value for potential fuel production from waste.
\end{abstract}

Keywords - Morphological composition; pre-treatment; solid recovered fuel; quality

\begin{tabular}{|lll}
\hline Nomenclature & & \\
$R D F$ & Refuse derived fuel & - \\
$S R F$ & Solid recovered fuel & - \\
$W E E E$ & Waste electrical and electronic equipment & - \\
$P V C$ & Polyvinyl chloride & - \\
$N C V$ & Net calorific value & $\mathrm{MJ} \mathrm{kg}^{-1}$ \\
\hline
\end{tabular}

\section{INTRODUCTION}

For about 20 years refuse derived fuel (RDF) and solid recovered fuel (SRF) have been produced from municipal solid waste globally (MSW). In Lithuania and Estonia, RDF preparation started in 2013 for Waste-to-Energy plants. In Latvia, production of RDF started in 2012 as an alternate fuel for a cement plant [1]. All ten waste landfills in Latvia have

\footnotetext{
* Corresponding author.

E-mail address: dace.arina@gmail.com 
mechanical pre-treatment equipment, but RDF (EU waste code: 191210) is produced by five companies. In Estonia, Latvia and Lithuania, part of the RDF is imported, which as explained by combusting companies is because of higher quality of imported RDF (especially of highest calorific value), the low solvency of local waste managing companies (the owners of RDF are paying for to incinerating their RDF) as well as their inability to provide large amount of waste. RDF as a fuel for production of cement has been imported to Latvia since 2008 [2]. About 123000 tons of RDF were imported and only 15000 tons were produced locally for the cement plant in Latvia in 2014. According to the Latvian Environment, Geology and Meteorology Centre, 103000 tons were imported and 26000 tons of RDF were produced in Latvia in 2018. Non-sufficient amount and quality of Latvia's MSW are the main obstacles to increasing production of RDF in Latvia.

According to [3], about $30 \%$ of MSW has the potential to be used for the RDF production, but according to the EU requirements for the MSW waste recycling and landfilling restrictions, potential for the RDF production is 20-25\%.

Potentially $2-3 \%$ of Latvia's energetic needs could be ensured by fuel produced from municipal waste as shown by approximate estimates [3].

According to [4], without thermic recovery of waste it is not possible to achieve the EU target of landfilling not being more than $10 \%$ of MSW.

SRF is a fuel produced from non-hazardous waste and sampled and tested in accordance with EU Standard EN 15359. RDF is a fuel produced from waste, it is a non-defined term and refers to waste that has not undergone proper processing and is not standardized [5]. RDF calorific value (RDF pellets $\sim 18 \mathrm{MJ} / \mathrm{kg}$ ) is competitive to fossil fuels and biomass as after mechanical pretreatment of MSW the organic part of RDF contains such high calorific fractions as paper, plastic, rubber, textiles, wood [6].

This study continues previous research [1], [7] on the fuel production potential of mixed MSW. In previous research, it was concluded that the quality of RDF from the coarse fraction of unsorted (mixed) MSW does not correspond to fuel needs for the production of cement. Inadequacies are: 1) high moisture content (large quantity of biological waste) and thus - low heating value, 2) increased ash content, as well as 3) increased $\mathrm{Cl}$ content. It was also concluded that additional processing is needed for the coarse fraction to be used for the production of fuel. If biological waste is separated at the source, better material for fuel production can be ensured.

Aim of the study is to characterize the RDF quality if bio-waste is partially separated at source. There are three municipalities where biological waste (food and green waste) is separated at the source in Latvia. MSW from one of these municipalities was used for this study. According to the EU, biological waste source separation and treatment should be started in all Baltic states. Study shows parameters of RDF from mixed MSW after mechanical pre-treatment.

\section{Methods ANd Methodology}

RDF samples were obtained from two mechanical biological treatment (MBT) plants for municipal solid waste in 2017-2018, one in Latvia and one in Lithuania. Description of processes and equipment used is given in Table 1. 
TABLE 1. MBT TECHNOLOGIES USED FOR PREPARATION OF RFD

Alytus

Viduskurzeme
waste management
organization

Viduskurzeme organization

\begin{abstract}
Mechanical/manual sorting line for separation of the bulky waste, non-combustible and hazardous waste. Mechanical processing equipment is: shredder $(<300 \mathrm{~mm})$, separator of metals and drum screener. The fraction from 20 to $80 \mathrm{~mm}$ separated by the drum separator passes through an electromagnetic separator and an eddy current separator and then is sent to the biological treatment facility (dry anaerobic digestion and filtering with a bacterial mixture). The technical compost is then treated mechanically in the drum screener separating the small fraction of compost and the lighter fraction of SRF. The flow that is greater than $80 \mathrm{~mm}$ is separated by air stream, then shredded for RDF.
\end{abstract}

\begin{abstract}
Mechanical processing equipment is: bag opener, drum screener $(<60 \mathrm{~mm})$ and magnetic separator of metal, manual sorting line (places for 8 people), a metal detector and cutting mill $(30 \times 30 \mathrm{~mm})$ for RDF and SRF preparation. Fine fraction $(<60 \mathrm{~mm})$ is sent to biological treatment - composting - for the production of technical compost. Coarse fraction $(>60 \mathrm{~mm})$ without rejection (hazardous waste, WEEE waste, PVC plastic waste, glass, stones) is mixed with a source separated plastic waste (that cannot be recycled) and then shredded by cutting mill.
\end{abstract}

Coarse fraction/RDF samples were taken before final shredding, SRF samples (Viduskurzeme) after shredding by cutting mill.

Specially collected mixed MSW from the municipality with biological waste separation at source was used for the study. Thus, incoming MSW mass contained less biological waste.

RDF and SRF samples were manually sorted and each fraction was weighed (scales precision $20 \mathrm{~g}$ and $0.1 \mathrm{~g}$ ). The morphological composition for the following main types was determined - paper and cardboard; plastics; biological waste (food waste and green waste); fine particles; textiles, rubber and leather; wood; metal; inert (glass, ceramics, stones) and other.

The study results for morphological composition of the fine fraction for four seasons were published [8] as well as for morphological composition of the coarse fraction for the summer season in Latvia [2].

In order to prepare representative samples for laboratory analysis, the samples were grained and formed. The detection of the parameters of the waste materials were conducted within the laboratory of the Institute of Physical Energetics in Latvia. For samples from Latvia the following parameters were determined according to the standards:

- Moisture content - LVS EN 15414-3:2011;

- Net calorific value - LVS EN 15400:2011;

- Ash content - LVS EN 15403:2011;

- Chlorine content - LVS EN 15408:2011;

- Sulphur content - LVS EN 15408:2011;

- C, H, N content - LVS EN 15407:2011;

- Content of trace elements - LVS EN 15411:2012;

- Content of major elements - LVS EN 15410:2012.

The equipment used for analysis was a cutting mill Retsch SM100; a bomb calorimeter Berthelot Mahler I.C.Co.; the equipment used for elemental analysis was a Thermo Scientific FlashEA 1112.; scale Mettler Toledo; spectrometer CLR-7K'XRF. 


\section{Results}

Table 2 shows the study results of the morphological composition of mixed MSW from Latvia and Lithuania.

TABle 2. The Average Morphological Composition of COARSE Fraction AND SRF of MiXed MUNiCIPAL SOLID WASTE (W, \%)

\begin{tabular}{lccc}
\hline Type of waste & $\begin{array}{l}\text { Coarse fraction/RDF from } \\
\text { Viduskurzeme, } \mathbf{~} \%\end{array}$ & $\begin{array}{l}\text { Coarse fraction/RDF } \\
\text { from Alytus, w } \%\end{array}$ & $\begin{array}{l}\text { SRF from Viduskurzeme, } \\
\mathbf{w} \%\end{array}$ \\
\hline $\begin{array}{l}\text { Paper and } \\
\text { cardboard }\end{array}$ & 16.5 & 14.2 & 18.7 \\
\hline Plastics & 38.6 & 39.5 & 52.1 \\
\hline Biological waste & 3.0 & 0.4 & 0.9 \\
Fine & 2.0 & 2.0 & 1.6 \\
Nappies & 21.9 & 2.7 & 9.9 \\
Textiles & 12.2 & 32.1 & 1.4 \\
Rubber, leather & 2.5 & 1.9 & 2.0 \\
Wood & 2.0 & 2.2 & 0.2 \\
Metal & 0.2 & 1.7 & 0.9 \\
Inert & 1.1 & 0.0 & 0.0 \\
Others & 0.0 & 3.3 & \\
\hline
\end{tabular}

Results show that the composition of paper and cardboard and plastic of the coarse fraction in Latvia and Lithuania are not significantly different. Differences of biological waste and nappies composition can be explained by the larger screen size $(<80 \mathrm{~mm})$ of Alytus MBT screener. Therefore, biological waste and nappies are less represented in the coarse fraction if compared to Viduskurzemes MBT with a screener size $<60 \mathrm{~mm}$. There are about 2,6 time more textiles in Alytus MBT. Textile forms the fourth largest part of the coarse fraction also for Viduskurzemes MBT.

The main difference for the SRF fraction in Viduskurzemes MBT is plastic as the largest part. It is explained by an additional plastic that is added for the SRF preparation process. Plastic, paper and cardboard, nappies and textiles form the four largest parts also for SRF.

Table 3 and Table 4 show results of analyses of coarse fraction and SRF from Latvia.

Results of the moisture analysis show significant differences of average values between the coarse fraction and the SRF fraction. That is explained by dry plastic waste that is added for SRF preparation. A little larger NCV and little less amount of ash in the SRF fraction can be explained by the same. According to [10], [11], the plastic fraction has a higher heating value compared to the paper and wood fraction. Other parameters, including element content, are similar. 
TABle 3. The Mean Values of the Parameters of CoARse Fraction AND SRF OF MIXED MUNICIPAL SOLID WASTE

\begin{tabular}{lccc}
\hline Parameter & $\begin{array}{c}\text { Coarse fraction/RDF } \\
\text { from Viduskurzeme }\end{array}$ & SRF from Viduskurzeme & $\begin{array}{l}\text { RDF from Estonia and } \\
\text { Latvia (data from literature) [9] }\end{array}$ \\
\hline Moisture, \% & 26.4 & 13.1 & 15.0 \\
NCV, MJ kg $^{-1}$ & 18.3 & 22.1 & 22.5 \\
Ash, \% & 14.9 & 10.4 & 10.0 \\
Cl, \% & 0.8 & 0.7 & 1.6 \\
S, \% & 0.2 & 0.1 & 0.4 \\
$\mathbf{N}, \%$ & 0.9 & 0.6 & 0.9 \\
$\mathbf{C ,} \%$ & 59.4 & 60.5 \\
$\mathbf{H}, \%$ & 7.0 & 7.6 & 9.0 \\
\hline
\end{tabular}

TABle 4. THE ElEMENTAL CONTENT OF COARSE FraCtion AND SRF OF MiXed MuniCIPAL SOLID WASTE

Elements Coarse fraction/RDF from Viduskurzeme SRF from Viduskurzeme, $\%$

\begin{tabular}{lcc}
\hline $\mathbf{H g}, \%$ & $\leq 0.001$ & $\leq 0.001$ \\
$\mathbf{C d}, \%$ & 0.001 & 0.001 \\
$\mathrm{As}, \%$ & $\leq 0.2$ \\
$\mathbf{C r}, \%$ & $<0.2$ & $<1$ \\
$\mathbf{C u}, \%$ & $<1$ & $<1$ \\
$\mathbf{P b}, \%$ & $<2$ & 0.1 \\
$\mathbf{M n}, \%$ & 0.2 & 0.1 \\
$\mathbf{N i}, \%$ & 0.1 & 0.02 \\
$\mathbf{S n}, \%$ & 0.03 & 0.03 \\
$\mathbf{V}, \%$ & 0.03 & 0.01 \\
\hline
\end{tabular}

\section{Discussion}

There are no significant differences in the main composition fractions if the results of the study are compared to other research of RDF morphological composition in Estonia and Latvia [9], [12]; plastic fraction varies 33-56 \% and paper, cardboard, wood fraction varies $7-25 \%$ and textile varies $4-33 \%$. According to research in Finland [13] for SRF content 
from household waste (collected as "energy waste") incoming mass has plastic - 28.6\%, paper and cardboard $-24.5 \%$ and textile $-8.8 \%$, but SRF has plastic $-32.6 \%$, paper and cardboard $-30 \%$. As shown in [14]-[16], the largest part of SRF is paper and cardboard. Also, from [11], the literature summary on research on RDF content shows paper and cardboard as the largest part.

With regard to the paper and cardboard fraction in RDF and SRF, this study has significant differences, as the main fraction is plastic. It can be explained that mainly only beverage PET was collected separately and sorting activity was not high. Therefore, the largest part of plastic enters MSW. According to [17], SRF content for fuel for the production of cement is an average $26.1 \%$ of plastic in the kiln and $52.63 \%$ of plastic in the primary burner, but paper and cardboard respectively $26.4 \%$ and $7.1 \%$. According to [18], research on SRF composition comparing years 2014 and 2018, an average value of plastic decreases from $28 \%$ to $19.8 \%$, thus decreasing the NCV as well from $19.3 \mathrm{MJ} \mathrm{kg}^{-1}$ to $17.7 \mathrm{MJ} \mathrm{kg}^{-1}$.

Besides NCV and mercury content, $\mathrm{Cl}$ content is the third parameter to assess the quality of SRF according to CEN standard (EN 15359). Results show that the mean value of chlorine corresponds to the third class $(\leq 1.0 \%)$ for the coarse fraction and the SRF fraction. If compared to previous research [11], an average content of $\mathrm{Cl}$ varies $-0.2-2.2 \%$ in $\mathrm{RDF}$, but globally it is on average $0.5 \%$. According to [19], approximately one-half of the chlorine content comes from PVC, while the second half are chlorides of alkali metals coming from organic waste.

Regarding heavy metals, the limitations is stated for mercury. Class 1 for the mercury is less than $0.02 \mathrm{mg} \mathrm{MJ}^{-1}$ (median) and $0.04 \mathrm{mg} \mathrm{MJ}^{-1}\left(80^{\text {th }}\right.$ percentile); class 2 is less than $0.03 \mathrm{mg} \mathrm{MJ}^{-1}$ (median) and $0.06 \mathrm{mg} \mathrm{MJ}^{-1}\left(80^{\text {th }}\right.$ percentile); class 3 is less than $0.08 \mathrm{mg} \mathrm{MJ}^{-1}$ (median) and $0.16 \mathrm{mg} \mathrm{MJ}^{-1}\left(80^{\text {th }}\right.$ percentile). In the case of mercury, the worst case of the two statistical values (i.e. the median and the $80^{\text {th }}$ percentile) takes precedence when determining the class of $\mathrm{Hg}$ content.

Results of NCV show that mean value for coarse fraction corresponds to third class of the EU standard ( $\left.\geq 15 \mathrm{MJ} \mathrm{kg}^{-1}\right)$, but the SRF fraction - to second class $\left(\geq 20 \mathrm{MJ} \mathrm{kg}^{-1}\right)$. Such results are typical for SRF.

\section{CONCLUSION}

The results from the Latvia and Lithuania case studies for composition of coarse fraction/RDF shows similar results (main types of waste are plastic, paper and cardboard and textile, for Latvia also nappies).

Source separation of biological waste from mixed MSW ensures the possibility of preparation of quality fuel for cement production (lower moisture content, higher heating value, lower ash content compared to unsorted MSW). Biologically degradable waste separation at the source is necessary to lower moisture and ash content and to increase heating value for potential fuel production from waste.

It is possible to lower $\mathrm{Cl}$ content if manual sorting of PVC waste is included into the process of RDF preparation.

The quality parameters of SRF are improved by additional plastic waste added to its preparation (that plastic is separately collected, dry and not recyclable).

The mean parameters for the coarse fraction/RDF can be classified with the class code: Net heating value (3); chlorine (3); mercury (1), and responds to limits stated for $3^{\text {rd }}$ class of SRF.

The mean parameters for SRF can be classified with the class code: Net heating value (2); chlorine (3); mercury (1), and responds to limits stated for $3^{\text {rd }}$ class of SRF. 


\section{ACKNOWLEDGEMENT}

The research has been worked out by co-financial support of the European Regional Development Fund for the postdoctoral project "Research of optical and energetic properties of mixed municipal solid waste material for its preparation for a recovery" No. 1.1.1.2/VIAA/1/16/221; and Estonian Grant 8P170055MIVE.

\section{REFERENCES}

[1] Arina D., Orupe A. Characteristics of Mechanically Sorted Municipal Wastes and Their Suitability for Production of Refuse Derived Fuel. Environmental and Climate Technologies 2012:8(1):18-23. https://doi.org/10.2478/v10145-0120003-0

[2] Arina D., Bendere R., Kalnacs J. Waste products - RDF or SRF as energy source in EU. Proceedings of 6th International Conference on Sustainable Solid Waste Management, Naxos Island, Greece, 2018. [Online]. [Accessed 10.02.2020]. Available from: http://uest.ntua.gr/naxos2018/proceedings/pdf/NAXOS2018_Arina_etal.pdf

[3] Dace E., Blumberga D. An assessment of the potential of refuse-derived fuel in Latvia. Mañagement of Environmental Quality 2012:23(5):503-516. https://doi.org/10.1108/14777831211255088

[4] Luoranen M., Horttanainen M. Feasibility of energy recovery from municipal solid waste in an integrated municipal energy supply and waste management system. Waste Management \& Research 2007:25:426-439. https://doi.org/10.1177\%2F0734242X07076943

[5] European Recovered Fuel Organization (ERFO). The role of SRF in a Circular Economy. [Online]. [Accessed 10.02.2020]. Available from: https://www.erfo.info/images/PDF/The_role_of_SRF_in_a_Circular_Economy.pdf

[6] Garg A., et al. Wastes as co-fuels: the policy framework for solid recovered fuel (SRF) in Europe, with UK implications. Environmental Science and Technology 2007:41(14):4868-4874. https://doi.org/10.1021/es062163e

[7] Arina D., Orupe A. Comparison of municipal solid waste characteristics after separation by star and drum screen systems. Proceedings of the 4th International Conference Civil Engineering '13. Jelgava: Latvia University of Agriculture 2013:1:318-322.

[8] Ārina D. et al. Mechanical pre-treatment for the separation of bio-waste from municipal solid waste: case study of district in Latvia. 19th International Scientific Conference on Engineering for Rural Development, Jelgava, Latvia, 2019. [Online]. [Accessed 10.02.2020]. Available: http://www.tf.1lu.lv/conference/proceedings2019/Papers/N206.pdf

[9] Porshnov D., Arina D., Klavins M. Composition of Refuse Derived Fuels in Latvia and Estonia in Comparision with Worldwide Average Values. Environment. Technology. Resources 2019:1:225-228. https://doi.org/10.17770/etr2019vol1.4128

[10] Rotter V. S. et al. New techniques for the characterization of refuse-derived fuels and solid recovered fuels. Waste Management and Research 2011:29(2):229-236. https://doi.org/10.1177/0734242X10364210

[11] Montejo C. et al. Analysis and comparison of municipal solid waste and reject fraction as fuels for incineration plants. Applied Thermal Engineering 2011:31(13):2135-2140. https://doi.org/10.1016/j.applthermaleng.2011.03.041

[12] Porshnov D. et al. Thermal decomposition study of major refuse derived fuel components. Energy Procedia 2018:147:48-53. https://doi.org/10.1016/j.egypro.2018.07.032

[13] Nasrullah M. et al. Mass, energy and material balances of SRF production process. Part 3: Solid recovered fuel produced from municipal solid waste. Waste Management and Research 2015:25:426-439. https://doi.org/10.1177/0734242X14563375

[14] Velis C. A. et al. Production and quality assurance of solid recovered fuels using mechanical-biological treatment (MBT) of waste: a comprehensive assessment. Critical Reviews in Environmental Science and Technology 2010:40:979-1105. https://doi.org/10.1080/10643380802586980

[15] Velis C. et al. Solid recovered fuel: Influence of waste stream composition and processing on chlorine content and fuel quality. Environmental Science and Technology 2012:46(3):1923-1931. https://doi.org/10.1021/es2035653

[16] Velis C. A. et al. Solid recovered fuel: materials flow analysis and fuel property development during the mechanical processing of biodried waste. Environmental Science and Technology 2013:47(6):2957-2965 https://doi.org/10.1021/es3021815

[17] Lorber K. E., Sarc R., Aldrian A. Design and quality assurance for solid recovered fuel. Waste Management and Research 2012:30(4):370-380. https://doi.org/10.1177/0734242X12440484

[18] Sarc R. et al. Design, quality and quality assurance of solid recovered fuels for the substitution of fossil feedstock in the cement industry - Update 2019. Waste Management and Research 2019:37(9):885-897. https://doi.org/10.1177/0734242X19862600

[19] Chatziaras N., Psomopoulos C. S., Themelis N. J. Use of waste derived fuels in cement industry: a review. Management of Environmental Quality 2016:27(2):178-193. https://doi.org/10.1108/MEQ-01-2015-0012 